\title{
THE USEFULNESS OF USELESS KNOWLEDGE
}

\author{
BY ABRAHAM FLEXNER
}

$\mathrm{I}^{\mathrm{s}}$ IT not a curious fact that in a world steeped in irrational hatreds which threaten civilization itself, men and women-old and young-detach themselves wholly or partly from the angry current of daily life to devote themselves to the cultivation of beauty, to the extension of knowledge, to the cure of disease, to the amelioration of suffering, just as though fanatics were not simultaneously engaged in spreading pain, ugliness, and suffering? The world has always been a sorry and confused sort of place-yet poets and artists and scientists have ignored the factors that would, if attended to, paralyze them. From a practical point of view, intellectual and spiritual life is, on the surface, a useless form of activity, in which men indulge because they procure for themselves greater satisfactions than are otherwise obtainable. In this paper I shall concern myself with the question of the extent to which the pursuit of these useless satisfactions proves unexpectedly the source from which undreamed-of utility is derived.

We hear it said with tiresome iteration that ours is a materialistic age, the main concern of which should be the wider distribution of material goods and worldly opportunities. The justified outcry of those who through no fault of their own are deprived of opportunity and a fair share of worldly goods therefore diverts an increasing number of students from the studies which their fathers pursued to the equally important and no less urgent study of social, economic, and govern- mental problems. I have no quarrel with this tendency. The world in which we live is the only world about which our senses can testify. Unless it is made a better world, a fairer world, millions will continue to go to their graves silent, saddened, and embittered. I have myself spent many years pleading that our schools should become more acutely aware of the world in which their pupils and students are destined to pass their lives. Now I sometimes wonder whether that current has not become too strong and whether there would be sufficient opportunity for a full life if the world were emptied of some of the useless things that give it spiritual significance; in other words, whether our conception of what is useful may not have become too narrow to be adequate to the roaming and capricious possibilities of the human spirit.

We may look at this question from two points of view: the scientific and the humanistic or spiritual. Let us take the scientific first. I recall a conversation which I had some years ago with $\mathrm{Mr}$. George Eastman on the subject of use. Mr. Eastman, a wise and gentle farseeing man, gifted with taste in music and art, had been saying to me that he meant to devote his vast fortune to the promotion of education in useful subjects. I ventured to ask him whom he regarded as the most useful worker in science in the world. He replied instantaneously: "Marconi." I surprised him by saying, "Whatever pleasure we 
derive from the radio or however wireless and the radio may have added to human life, Marconi's share was practically negligible."

I shall not forget his astonishment on this occasion. He asked me to explain. I replied to him somewhat as follows:

"Mr. Eastman, Marconi was inevitable. The real credit for everything that has been done in the field of wireless belongs, as far as such fundamental credit can be definitely assigned to anyone, to Professor Clerk Maxwell, who in 1865 carried out certain abstruse and remote calculations in the field of magnetism and electricity. Maxwell reproduced his abstract equations in a treatise published in 1873. At the next meeting of the British Association Professor H. J. S. Smith of Oxford declared that 'no mathematician can turn over the pages of these volumes without realizing that they contain a theory which has already added largely to the methods and resources of pure mathematics.' Other discoveries supplemented Maxwell's theoretical work during the next fifteen years. Finally in 1887 and 1888 the scientific problem still remaining-the detection and demonstration of the electromagnetic waves which are the carriers of wireless signals -was solved by Heinrich Hertz, a worker in Helmholtz's laboratory in Berlin. Neither Maxwell nor Hertz had any concern about the utility of their work; no such thought ever entered their minds. They had no practical objective. The inventor in the legal sense was of course Marconi, but what did Marconi invent? Merely the last technical detail, mainly the now obsolete receiving device called coherer, almost universally discarded."

Hertz and Maxwell could invent nothing, but it was their useless theoretical work which was seized upon by a clever technician and which has created new means for communication, utility, and amusement by which men whose merits are relatively slight have obtained fame and earned millions. Who were the useful men? Not Marconi, but Clerk Maxwell and Heinrich Hertz. Hertz and Maxwell were geniuses without thought of use. Marconi was a clever inventor with no thought but use.

The mention of Hertz's name recalled to Mr. Eastman the Hertzian waves, and I suggested that he might ask the physicists of the University of Rochester precisely what Hertz and Maxwell had done; but one thing I said he could be sure of, namely, that they had done their work without thought of use and that throughout the whole history of science most of the really great discoveries which had ultimately proved to be beneficial to mankind had been made by men and women who were driven not by the desire to be useful but merely the desire to satisfy their curiosity.

"Curiosity?" asked Mr. Eastman.

"Yes," I replied, "curiosity, which may or may not eventuate in something useful, is probably the outstanding characteristic of modern thinking. It is not new. It goes back to Galileo, Bacon, and to Sir Isaac Newton, and it must be absolutely unhampered. Institutions of learning should be devoted to the cultivation of curiosity and the less they are deflected by considerations of immediacy of application, the more likely they are to contribute not only to human welfare but to the equally important satisfaction of intellectual interest which may indeed be said to have become the ruling passion of intellectual life in modern times."

\section{II}

What is true of Heinrich Hertz working quietly and unnoticed in a corner of Helmholtz's laboratory in the later years of the nineteenth century may be said of scientists and mathematicians the world over for several centuries past. We live in a world that would be helpless without electricity. Called upon to mention a discovery of the most immediate and farreaching practical use we might well agree upon electricity. But who made the fundamental discoveries out of which the entire electrical development of more than one hundred years has come? 
The answer is interesting. Michael Faraday's father was a blacksmith; Michael himself was apprenticed to a bookbinder. In 1812, when he was already twenty-one years of age, a friend took him to the Royal Institution where he heard Sir Humphrey Davy deliver four lectures on chemical subjects. $\mathrm{He}$ kept notes and sent a copy of them to Davy. The very next year, 1813, he became an assistant in Davy's laboratory, working on chemical problems. Two years later he accompanied Davy on a trip to the Continent. In 1825, when he was thirty-four years of age, he became Director of the Laboratory of the Royal Institution where he spent fifty-four years of his life.

Faraday's interest soon shifted from chemistry to electricity and magnetism, to which he devoted the rest of his active life. Important but puzzling work in this field had been previously accomplished by Oersted, Ampère, and Wollaston. Faraday cleared away the difficulties which they had left unsolved and by 1841 had succeeded in the task of induction of the electric current. Four years later a second and equally brilliant epoch in his career opened when he discovered the effect of magnetism on polarized light. His earlier discoveries have led to the infinite number of practical applications by means of which electricity has lightened the burdens and increased the opportunities of modern life. His later discoveries have thus far been less prolific of practical results. What difference did this make to Faraday? Not the least. At no period of his unmatched career was he interested in utility. He was absorbed in disentangling the riddles of the universe, at first chemical riddles, in later periods, physical riddles. As far as he cared, the question of utility was never raised. Any suspicion of utility would have restricted his restless curiosity. In the end, utility resulted, but it was never a criterion to which his ceaseless experimentation could be subjected.

In the atmosphere which envelopes the world to-day it is perhaps timely to em- phasize the fact that the part played by science in making war more destructive and more horrible was an unconscious and unintended by-product of scientific activity. Lord Rayleigh, president of the British Association for the Advancement of Science, in a recent address points out in detail how the folly of man, not the intention of the scientists, is responsible for the destructive use of the agents employed in modern warfare. The innocent study of the chemistry of carbon compounds, which has led to infinite beneficial results, showed that the action of nitric acid on substances like benzene, glycerine, cellulose, etc., resulted not only in the beneficent aniline dye industry but in the creation of nitroglycerine, which has uses good and bad. Somewhat later Alfred Nobel, turning to the same subject, showed that by mixing nitro-glycerine with other substances, solid explosives which could be safely handled could be produced-among others, dynamite. It is to dynamite that we owe our progress in mining, in the making of such railroad tunnels as those which now pierce the Alps and other mountain ranges; but of course dynamite has been abused by politicians and soldiers. Scientists are, however, no more to blame than they are to blame for an earthquake or a flood. The same thing can be said of poison gas. Pliny was killed by breathing sulphur dioxide in the eruption of Vesuvius almost two thousand years ago. Chlorine was not isolated by scientists for warlike purposes, and the same is true of mustard gas. These substances could be limited to beneficent use, but when the airplane was perfected, men whose hearts were poisoned and whose brains were addled perceived that the airplane, an innocent invention, the result of long disinterested and scientific effort, could be made an instrument of destruction, of which no one had ever dreamed and at which no one had ever deliberately aimed.

In the domain of higher mathematics almost innumerable instances can be cited. For example, the most abstruse 
mathematical work of the eighteenth and nineteenth centuries was the "NonEuclidian Geometry." Its inventor, Gauss, though recognized by his contemporaries as a distinguished mathematician, did not dare to publish his work on "Non-Euclidian Geometry" for a quarter of a century. As a matter of fact, the theory of relativity itself with all its infinite practical bearings would have been utterly impossible without the work which Gauss did at Göttingen.

Again, what is known now as "group theory" was an abstract and inapplicable mathematical theory. It was developed by men who were curious and whose curiosity and puttering led them into strange paths; but "group theory" is to-day the basis of the quantum theory of spectroscopy, which is in daily use by people who have no idea as to how it came about.

The whole calculus of probability was discovered by mathematicians whose real interest was the rationalization of gambling. It has failed of the practical purpose at which they aimed, but it has furnished a scientific basis for all types of insurance, and vast stretches of nineteenth century physics are based upon it.

From a recent number of Science I quote the following:

The stature of Professor Albert Einstein's genius reached new heights when it was disclosed that the learned mathematical physicist developed mathematics fifteen years ago which are now helping to solve the mysteries of the amazing fluidity of helium near the absolute zero of the temperature scale. Before the symposium on intermolecular action of the American Chemical Society Professor F. London, of the University of Paris, now visiting professor at Duke University, credited Professor Einstein with the concept of an "ideal" gas which appeared in papers published in 1924 and 1925 .

The Einstein 1925 reports were not about relativity theory, but discussed problems seemingly without any practical significance at the time. They described the degeneracy of an "ideal" gas near the lower limits of the scale of temperature. Because all gases were known to be condensed to liquids at the temperatures in question, scientists rather overlooked the Einstein work of fifteen years ago.

However, the recently discovered behavior of liquid helium has brought the side-tracked Einstein concept to new usefulness. Most liquids increase in viscosity, become stickier and flow less easily, when they become colder. The phrase "colder than molasses in January" is the layman's concept of viscosity and a correct one.

Liquid helium, however, is a baffling exception. At the temperature known as the "delta" point, only 2.19 degrees above absolute zero, liquid helium flows better than it does at higher temperatures and, as a matter of fact, the liquid helium is about as nebulous as a gas. Added puzzles in its strange behavior include its enormous ability to conduct heat. At the delta point it is about 500 times as effective in this respect as copper at room temperature. Liquid helium, with these and other anomalies, has posed a major mystery for physicists and chemists.

Professor London stated that the interpretation of the behavior of liquid helium can best be explained by considering it as a Bose-Einstein "ideal" gas, by using the mathematics worked out in 1924-25, and by taking over also some of the concepts of the electrical conduction of metals. By simple analogy, the amazing fluidity of liquid helium can be partially explained by picturing the fluidity as something akin to the wandering of electrons in metals to explain electrical conduction.

Let us look in another direction. In the domain of medicine and public health the science of bacteriology has played for half a century the leading role. What is its story? Following the Franco-Prussian War of 1870, the German Government founded the great University of Strasbourg. Its first professor of anatomy was Wilhelm von Waldeyer, subsequently professor of anatomy in Berlin. In his Reminiscences he relates that among the students who went with him to Strasbourg during his first semester there was a small, inconspicuous, self-contained youngster of seventeen by name Paul Ehrlich. The usual course in anatomy then consisted of dissection and microscopic examination of tissues. Ehrlich paid little or no attention to dissection, but, as Waldeyer remarks in his Reminiscences:

I noticed quite early that Ehrlich would work long hours at his desk, completely absorbed in microscopic observation. Moreover, his desk gradually became covered with colored spots of every description. As I saw him sitting at work one day, I went up to him and asked what he 
was doing with all his rainbow array of colors on his table. Thereupon this young student in his first semester supposedly pursuing the regular course in anatomy looked up at me and blandly remarked, "Ich probiere." This might be freely translated, "I am trying" or "I am just fooling." I replied to him, "Very well. Go on with your fooling." Soon I saw that without any teaching or direction whatsoever on my part I possessed in Ehrlich a student of unusual quality.

Waldeyer wisely left him alone. Ehrlich made his way precariously through the medical curriculum and ultimately procured his degree mainly because it was obvious to his teachers that he had no intention of ever putting his medical degree to practical use. He went subsequently to Breslau where he worked under Professor Cohnheim, the teacher of our own Dr. Welch, founder and maker of the Johns Hopkins Medical School. I do not suppose that the idea of use ever crossed Ehrlich's mind. $\mathrm{He}$ was interested. He was curious; he kept on fooling. Of course his fooling was guided by a deep instinct, but it was a purely scientific, not an utilitarian motivation. What resulted? Koch and his associates established a new science, the science of bacteriology. Ehrlich's experiments were now applied by a fellow student, Weigert, to staining bacteria and thereby assisting in their differentiation. Ehrlich himself developed the staining of the blood film with the dyes on which our modern knowledge of the morphology of the blood corpuscles, red and white, is based. Not a day passes but that in thousands of hospitals the world over Ehrlich's technic is employed in the examination of the blood. Thus the apparently aimless fooling in Waldeyer's dissecting room in Strasbourg has become a main factor in the daily practice of medicine.

I shall give one example from industry, one selected at random; for there are scores besides. Professor Berl, of the Carnegie Institute of Technology (Pittsburgh) writes as follows:

The founder of the modern rayon industry was the French Count Chardonnet. It is known that he used a solution of nitro cotton in ether-alcohol, and that he pressed this viscous solution through capillaries into water which served to coagulate the cellulose nitrate filament. After the coagulation, this filament entered the air and was wound up on bobbins. One day Chardonnet inspected his French factory at Besançon. By an accident the water which should coagulate the cellulose nitrate filament was stopped. The workmen found that the spinning operation went much better without water than with water. This was the birthday of the very important process of dry spinning, which is actually carried out on the greatest scale.

\section{III}

I am not for a moment suggesting that everything that goes on in laboratories will ultimately turn to some unexpected practical use or that an ultimate practical use is its actual justification. Much more am I pleading for the abolition of the word "use," and for the freeing of the human spirit. To be sure, we shall thus free some harmless cranks. To be sure, we shall thus waste some precious dollars. But what is infinitely more important is that we shall be striking the shackles off the human mind and setting it free for the adventures which in our own day have, on the one hand, taken Hale and Rutherford and Einstein and their peers millions upon millions of miles into the uttermost realms of space and, on the other, loosed the boundless energy imprisoned in the atom. What Rutherford and others like Bohr and Millikan have done out of sheer curiosity in the effort to understand the construction of the atom has released forces which may transform human life; but this ultimate and unforeseen and unpredictable practical result is not offered as a justification for Rutherford or Einstein or Millikan or Bohr or any of their peers. Let them alone. No educational administrator can possibly direct the channels in which these or other men shall work. The waste, I admit again, looks prodigious. It is not really so. All the waste that could be summed up in developing the science of bacteriology is as nothing compared to the advantages which have accrued from the discoveries 
of Pasteur, Koch, Ehrlich, Theobald Smith, and scores of others-advantages that could never have accrued if the idea of possible use had permeated their minds. These great artists-for such are scientists and bacteriologists-disseminated the spirit which prevailed in laboratories in which they were simply following the line of their own natural curiosity.

I am not criticising institutions like schools of engineering or law in which the usefulness motive necessarily predominates. Not infrequently the tables are turned, and practical difficulties encountered in industry or in laboratories stimulate theoretical inquiries which may or may not solve the problems by which they were suggested, but may also open up new vistas, useless at the moment, but pregnant with future achievements, practical and theoretical.

With the rapid accumulation of "useless" or theoretic knowledge a situation has been created in which it has become increasingly possible to attack practical problems in a scientific spirit. Not only inventors, but "pure" scientists have indulged in this sport. I have mentioned Marconi, an inventor, who, while a benefactor to the human race, as a matter of fact merely "picked other men's brains." Edison belongs to the same category. Pasteur was different. He was a great scientist; but he was not averse to attacking practical problems - such as the condition of French grapevines or the problems of beer-brewing - and not only solving the immediate difficulty, but also wresting from the practical problem some far-reaching theoretic conclusion, "useless" at the moment, but likely in some unforeseen manner to be "useful" later. Ehrlich, fundamentally speculative in his curiosity, turned fiercely upon the problem of syphilis and doggedly pursued it until a solution of immediate practical use - the discovery of salvarsan - was found. The discoveries of insulin by Banting for use in diabetes and of liver extract by Minot and Whipple for use in pernicious anemia belong in the same category: both were made by thoroughly scientific men, who realized that much "useless" knowledge had been piled up by men unconcerned with its practical bearings, but that the time was now ripe to raise practical questions in a scientific manner.

Thus it becomes obvious that one must be wary in attributing scientific discovery wholly to any one person. Almost every discovery has a long and precarious history. Someone finds a bit here, another a bit there. A third step succeeds later and thus onward till a genius pieces the bits together and makes the decisive contribution. Science, like the Mississippi, begins in a tiny rivulet in the distant forest. Gradually other streams swell its volume. And the roaring river that bursts the dikes is formed from countless sources.

I cannot deal with this aspect exhaustively, but I may in passing say this: over a period of one or two hundred years the contributions of professional schools to their respective activities will probably be found to lie, not so much in the training of men who may to-morrow become practical engineers or practical lawyers or practical doctors, but rather in the fact that even in the pursuit of strictly practical aims an enormous amount of apparently useless activity goes on. Out of this useless activity there come discoveries which may well prove of infinitely more importance to the human mind and to the human spirit than the accomplishment of the useful ends for which the schools were founded.

The considerations upon which I have touched emphasize-if emphasis were needed - the overwhelming importance of spiritual and intellectual freedom. I have spoken of experimental science; I have spoken of mathematics; but what I say is equally true of music and art and of every other expression of the untrammeled human spirit. The mere fact that they bring satisfaction to an individual soul bent upon its own purification and elevation is all the justification that they need. And in justifying these without 
any reference whatsoever, implied or actual, to usefulness we justify colleges, universities, and institutes of research. An institution which sets free successive generations of human souls is amply justified whether or not this graduate or that makes a so-called useful contribution to human knowledge. A poem, a symphony, a painting, a mathematical truth, a new scientific fact, all bear in themselves all the justification that universities, colleges, and institutes of research need or require.

The subject which I am discussing has at this moment a peculiar poignancy. In certain large areas-Germany and Italy especially - the effort is now being made to clamp down the freedom of the human spirit. Universities have been so reorganized that they have become tools of those who believe in a special political, economic, or racial creed. Now and then a thoughtless individual in one of the few democracies left in this world will even question the fundamental importance of absolutely untrammeled academic freedom. The real enemy of the human race is not the fearless and irresponsible thinker, be he right or wrong. The real enemy is the man who tries to mold the human spirit so that it will not dare to spread its wings, as its wings were once spread in Italy and Germany, as well as in Great Britain and the United States.

This is not a new idea. It was the idea which animated von Humboldt when, in the hour of Germany's conquest by Napoleon, he conceived and founded the University of Berlin. It is the idea which animated President Gilman in the founding of the Johns Hopkins University, after which every university in this country has sought in greater or less degree to remake itself. It is the idea to which every individual who values his immortal soul will be true whatever the personal consequences to himself. Justification of spiritual freedom goes, however, much farther than originality whether in the realm of science or humanism, for it implies tolerance throughout the range of human dissimilarities. In the face of the history of the human race what can be more silly or ridiculous than likes or dislikes founded upon race or religion? Does humanity want symphonies and paintings and profound scientific truth, or does it want Christian symphonies, Christian paintings, Christian science, or Jewish symphonies, Jewish paintings, Jewish science, or Mohammedan or Egyptian or Japanese or Chinese or American or German or Russian or Communist or Conservative contributions to and expressions of the infinite richness of the human soul?

\section{IV}

Among the most striking and immediate consequences of foreign intolerance I may, I think, fairly cite the rapid development of the Institute for Advanced Study, established by Mr. Louis Bamberger and his sister, Mrs. Felix Fuld, at Princeton, New Jersey. The founding of the Institute was suggested in 1930 . It was located at Princeton partly because of the founders' attachment to the State of New Jersey, but, in so far as my judgment was concerned, because Princeton had a small graduate school of high quality with which the most intimate cooperation was feasible. To Princeton University the Institute owes a debt that can never be fully appreciated. The work of the Institute with a considerable portion of its personnel began in 1933. On its faculty are eminent American scholars - Veblen, Alexander, and Morse, among the mathematicians; Meritt, Lowe, and Miss Goldman among the humanists; Stewart, Riefler, Warren, Earle, and Mitrany among the publicists and economists. And to these should be added scholars and scientists of equal caliber already assembled in Princeton University, Princeton's library, and its laboratories. But the Institute for Advanced Study is indebted to Hitler for Einstein, Weyl, and von Neumann in mathematics; for Herzfeld and Panofsky in the field of humanistic studies, and for a host 
of younger men who during the past six years have come under the influence of this distinguished group and are already adding to the strength of American scholarship in every section of the land.

The Institute is, from the standpoint of organization, the simplest and least formal thing imaginable. It consists of three schools - a School of Mathematics, a School of Humanistic Studies, a School of Economics and Politics. Each school is made up of a permanent group of professors and an annually changing group of members. Each school manages its own affairs as it pleases; within each group each individual disposes of his time and energy as he pleases. The members who already have come from twenty-two foreign countries and thirtynine institutions of higher learning in the United States are admitted, if deemed worthy, by the several groups. They enjoy precisely the same freedom as the professors. They may work with this or that professor, as they severally arrange; they may work alone, consulting from time to time anyone likely to be helpful. No routine is followed; no lines are drawn between professors, members, or visitors. Princeton students and professors and Institute members and professors mingle so freely as to be indistinguishable. Learning as such is cultivated. The results to the individual and to society are left to take care of themselves. No faculty meetings are held; no committees exist. Thus men with ideas enjoy conditions favorable to reflection and to conference. A mathematician may cultivate mathematics without distraction; so may a humanist in his field, an economist or a student of politics in his. Administration has been minimized in extent and importance. Men without ideas, without power of concentration on ideas, would not be at home in the Institute.

I can perhaps make this point clearer by citing briefly a few illustrations. A stipend was awarded to enable a Harvard professor to come to Princeton: he wrote asking,

"What are my duties?"
I replied: "You have no duties-only opportunities."

An able young mathematician, having spent a year at Princeton, came to bid me good-by. As he was about to leave, he remarked:

"Perhaps you would like to know what this year has meant to me."

"Yes," I answered.

"Mathematics," he rejoined, "is developing rapidly; the current literature is extensive. It is now over ten years since I took my Ph.D. degree. For a while I could keep up with my subject; but latterly that has become increasingly difficult and uncertain. Now, after a year here, the blinds are raised; the room is light; the windows are open. I have in my head two papers that I shall shortly write."

"How long will this last?" I asked.

"Five years, perhaps ten."

"Then what?"

"I shall come back."

A third example is of recent occurrence. A professor in a large Western university arrived in Princeton at the end of last December. He had in mind to resume some work with Professor Morey (at Princeton University). But Morey suggested that he might find it worth while to see Panofsky and Swarzenski (at the Institute). Now he is busy with all three.

"I shall stay," he added, "until next October."

"You will find it hot in midsummer," I said.

"I shall be too busy and too happy to notice it."

Thus freedom brings not stagnation, but rather the danger of overwork. The wife of an English member recently asked:

"Does everyone work until two o'clock in the morning?"

The Institute has had thus far no building. At this moment the mathematicians are guests of the Princeton mathematicians in Fine Hall; some of the humanists are guests of the Princeton humanists in McCormick Hall; others 
work in rooms scattered through the town. The economists now occupy a suite at The Princeton Inn. My own quarters are located in an office building on Nassau Street, where I work among shopkeepers, dentists, lawyers, chirnpractors, and groups of Princeton scholars conducting a local government survey and a study of population. Bricks and mortar are thus quite inessential, as President Gilman proved in Baltimore sixty-odd years ago. Nevertheless, we miss informal contact with one another and are about to remedy this defect by the erection of a building provided by the founders, to be called Fuld Hall. But formality shall go no farther. The Institute must remain small; and it will hold fast to the conviction that The Institute Group desires leisure, security, freedom from organization and routine, and, finally, informal contacts with the scholars of Princeton University and others who from time to time can be lured to Princeton from distant places. Among these Niels Bohr has come from Copenhagen, von Laue from Berlin, Levi Civita from Rome, André Weil from Strasbourg, Dirac and G. H. Hardy from Cambridge, Pauli from Zurich, Lemaitre from Louvain, Wade-Gery from Oxford, and Americans from Harvard, Yale, Columbia, Cornell, Johns Hopkins, Chicago, California, and other centers of light and learning.

We make ourselves no promises, but we cherish the hope that the unobstructed pursuit of useless knowledge will prove to have consequences in the future as in the past. Not for a moment, however, do we defend the Institute on that ground. It exists as a paradise for scholars who, like poets and musicians, have won the right to do as they please and who accomplish most when enabled to do so.

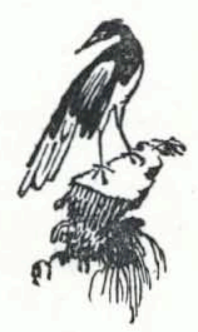

